Review Article

www.ijrap.net

\title{
ANTI-HEMORRHOIDAL DRUGS OF BHAVAPRAKASH NIGHANTU: A LITERARY SURVEY
}

Satej Banne*, Shraddha Nayak, Yogesh Girigaon, Nalinikanta Parida, Mahantkumar Naik

Department of Dravyaguna, KLEU, Shri BMK Ayurveda Mahavidyalaya, Belgaum, Karnataka, India

Received on: 13/05/14 Revised on: 20/07/14 Accepted on: 18/08/14

\begin{abstract}
*Corresponding author
Dr. Satej Tippanna Banne, PG Scholar, Department of Dravyaguna, Shri B.M. Kankanwadi Ayurveda Mahavidyalaya, Shahapur, Belgaum- 590003 Karnataka, India E-mail: satejbanne16@gmail.com

DOI: 10.7897/2277-4343.054111

ABSTRACT

Hemorrhoid is a lifestyle disease. Lifestyle disease is caused by a change in the way in which people live, as a result of the advancements in society or its scientific progress. Lack of adequate physical activity, no exercise, smoking, consumption of alcohol and irregular lifestyle patterns can be one of the main causes of these diseases. Hemorrhoid is one such lifestyle related disease. It can be effectively treated with over-the-counter medications, good fluid intake and by following a diet rich in fiber. Diet failure leads to many diseases including hemorrhoids, constipation, irritable bowel syndrome, ulcerative colitis and Crohn's disease. In severe cases, piles may require surgical intervention. Ayurveda plays vital role in curing Arsha (Hemorrhoids) and is explained under mamsaroga. Many treatment modalities have been explained in Brihatrayi (Charak, Sushruta, Vagbhata) and Laghutrayi (Sharangdhara, Bhavaprakash and Madhav Nidan). Bhavaprakash mentions numerous drugs acting on hemorrhoids. The present study was designed to screen the drugs with Arshoghna, Visheshat Gudajapaham and Raktarshara, Gudaraktahruta, Gudankurnash, Gudartinash, Vatarshahara properties. Out of 426 drugs 82 were described for the treatment of hemorrhoids throughout the text which includes herbal, mineral and animal origin drugs.
\end{abstract}

Keywords: Hemorrhoids, Arsha, Bhavaprakash Nighantu.

\section{INTRODUCTION}

Hemorrhoid is a very common medical complaint. Extrapolated incidence of hemorrhoids in India is $3,915,700$ and population used for this estimation were 1,065,070,607. These statistics are calculated extrapolations of various prevalence or incidence rates against the populations of a particular country or region. The statistics used for prevalence/incidence of Hemorrhoids are typically based on US, UK, Canadian or Australian prevalence or incidence statistics, which are then, extrapolated using only the population of the other country. Men are more likely than women to suffer from hemorrhoids that require professional medical treatment. ${ }^{1}$ Lifestyle diseases refer to diseases that result because of choices people make in their life. They are mostly common in developed nations where people are inclined towards eating unhealthy foods, having a sedentary lifestyle and unhealthy habits like smoking and drinking alcohol. ${ }^{2}$ Hemorrhoids are swollen blood vessels around the anus. Hemorrhoids may protrude externally or be internal to the body. Although hemorrhoids are definitely irritating and sometimes debilitating, they are almost never life-threatening or a symptom of something worse. $^{3}$ Analyze dincharya more concentration should be given to the charyas which will help us to balance the unhealthy lifestyle which we follow. Adopt the ritucharya (seasonal regimen) that can be followed by giving proper awareness about the changes that will take place during a ritu. ${ }^{4}$ for hemorrhoids many drugs have been mentioned in Ayurveda classics. Bhavaprakash Nighantu is one the important lexicon where lot of drugs has been mentioned. Bhavaprakash Nighantu mentions total 82 drugs which acts as anti-hemorrhoidal. There are six types of pilesthose caused by vata, pitta, kapha, rakta and sannipata and the congenital one told by Aacharya Sushruta. In unrestrained persons, by aforesaid exciting factors particularly viruddha (incompatible food), adhyashana (eating before previous food is digested), striprasanga (sexual intercourse), utkatukasana (squatting position), prusthayana (riding), vegavidharana (suppression of natural urges) etc. doshas-singly, dually, all or associated with blood are aggravated and spread to chief passages move downwards, reach anal folds and after vitiating them produce fleshy growths particularly in those having deficient digestive power; these tuber- like growth by rubbing with grass, wood, stone, cloth etc. or by the excessive contact of cold water develop further which are known as hemorrhoids. ${ }^{6}$ Rectum is attached to large intestine (descending colon) and measures four and half fingers. Therein are three folds, at the intervals of one and a half fingers, four fingers broad and all risen obliquely up to one finger- they are named as pravahani, visarjani and samvarani. ${ }^{6}$ They are situated one above the other like spiral of conch-shell and are similar to elephant's palate in color. Anal lip is raised one and a half barley from the hair-end. ${ }^{6}$ Charakacharya mentions that there are only ten seats where vital breath is located- such as - shankha pradesh (two temples), marmatraya (three vital organs heart, bladder and head), kantha (throat), rakta (blood), shukra (semen), ojas and guda (ano-rectal region). ${ }^{7}$ The learned physician who knows about these (vital seats), sense organs, consciousness, root of consciousness and disease, is known as the promoter of vital breath (life). ${ }^{7}$ Aacharya Sushruta and Ashtanga Sangrahakara mentions Arsha is one among ashta mahagada (cripple and fatal diseases) because of their incurable nature. Sushruta mentions this disease is difficult to cure or incurable. ${ }^{8}$ The minute essence of blood (Asruja) and kapha is acted upon by pitta followed by rushing of vayu, thereby intestines; anus and urinary bladder are formed. ${ }^{9}$ According to Aacharya charaka purishavaha strotas (channels carrying 
faeces) have their root in pakvashaya and sthulaguda (rectum). Purishavaha strotas are affected due to sandharana (holding up of the urge for defecation), atyashana (over- eating), ajeerna and adhyashana (eating during indigestion and when previous meal is not digested) particularly in person with durbalagni (poor digestion) and who are krush (lean and thin). ${ }^{10}$ Total seven kalas (membranes) also appear as structure intervening between dhatus (rasa, rakta etc.) and their seat asayas (viscera). Here dhatu also denotes doshas and malas as they too support the body. ${ }^{11}$ Of them, the first one is mamsadhara (muscle-supporting) in which, within the muscles, branches of blood vessels, ligaments, dhamani and channels are spread over. ${ }^{11}$ The diseases which are caused by affection of mamsa are Adhimamsa, arbuda (tumor), kila (arsha), galashaluka, galashundika, putimamsa, alaji, ganda, gandamala (cervical adenitis), upajihvika- those are located in mamsa. ${ }^{12}$ Premonitory symptoms of piles include anne-ashraddha (aversion to food), krucchat pakti (digestion with difficulty), amlika (hyperacidity), paridaha (generalized burning sensation), vishtambha (wind formation), pipasa (thirst), sakthisadana (weakness in legs), atopa (flatulence), karshya (emaciation), udgarabahulya (belching), akshno kshavathu (swelling in eyes), antrakujana (gurgling sound in bowels), gudaparikartana (cutting pain in anus), panduroga ashanka (doubt of anemia), grahani roga, kasa (cough), shwasa (dyspnoea), balahani (debility), bhrama (giddiness), tandra (drowsiness), nidra (excessive sleep) and indriyadourbalya (weakness of sense organs). ${ }^{13}$ The disease piles, complicated with thirst (trushna), anorexia (Arochaka), colic (shula), severe hemorrhage (atiprasruta shonita), edema (shopha) and diarrhea (atisara) brings end to the patient. ${ }^{14}$ In piles, one should abstains from suppression of urges, sex, riding, squatting position and food increasing respective dosha. ${ }^{15}$ Aacharya Sushruta mentions various oushadhi prayoga for Arsha. In morning, haritaki mixed with jaggery should be used regularly; or hundred fruits of haritaki should be cooked in cow's urine one drone (10.24 liters) and out of it, the celibate should take proper dose with honey according to strength every morning; or apamarga root with rice-water mixed with honey every day; or paste of shatavari root with milk; or the best sidhu mixed with bhallataka powder and saltless with buttermilk; or one should use in food and drink buttermilk, sour or non-sour formed in a jar pasted inside with pulp of citraka root; the formulation of buttermilk may be used with bharangi, asphota, yavani, amalaka and guduchi; the same with pippali, pippalimula, chavya, chitraka, vidanga, shunthi and haritaki; or without cereals buttermilk should be used daily for a month; or milk processed with decoction of shunthi, punarnava and chitraka; or hot infusion of kutaja root bark added with pippalyadi drugs along with honey, hingvadi churna mentioned under mahavatavyadhi should be used keeping on diet of buttermilk or milk; or boiled barley cooked with chitraka root and alkali water and salted with yavakshara; or milk processed with chitraka root and alkali-water or with alkali of palasa tree; or decanted alkali of patala, apamarga, bruhati and palasha mixed with ghee everyday; or paste of the roots of kutaja and vandaka with buttermilk; or ghee cooked with alkali-water added with pippalyadi drugs; or two palas ( $80 \mathrm{~g}$ ) or one pala (40 g) black sesame should be taken with cold water every morning. By these digestive fire is stimulated and hemorrhoids are alleviated. Bhallataka is indicated in piles caused by vata and kapha while kutaja is useful in those caused by rakta and pitta. ${ }^{16}$ Laghu vagbhata in Shodhanadi gana sangraha adhyaya states that Mushkakadi gana and vatsakadi gana helpful in arsha ${ }^{17}$ while Acharya Sushruta told that Mushkakadi gana helps in condition of Arsha in Dravyasangrahaniya adhyaya.18

\section{DISCUSSION}

Bhavamishra has given unique consideration to the disease arsha (hemorrhoids) and used various drugs to treat this disease. Present study deals with extensive variety of drugs from Bruhatrayis. Author has determined on herbal drugs rather than other diversity of group. (Table 1 to 6). Bhavamishra directly mentions the karma or action of these drugs as Arshoghna. There are mineral origin drugs which act as anti-hemorrhoids (Table 7). Drugs from whole Bhavaprakash Nighantu were screened for the action Arshoghna (anti hemorrhoid). Obtained data were presented as per anti-hemorrhoid action with respect to herbal, mineral and animal origin drugs which belongs to different vargas (chapter wise) classification with corresponding reference. Out of 426 drugs 12 (14.63\%) belong to Haritakyadi varga, $6(7.31 \%)$ of drugs from Karpuradi varga, 27 (32.92\%) belong to Guduchyadi varga, Pushpa varga has $2(2.43 \%)$ in Vatadi varga 8 $(9.75 \%)$ are stated, Amradiphala varga has $2(2.43 \%)$ and also Shaka varga $8(9.75 \%)$ were used for the treatment of arsha. At this point Bhavamishra mentioned more number of drugs (79.22\%) from herbal origin. Subsequent to herbal origin Dhatvadi varga 6 (7.31\%) has been stated in treatment of arsha. Following Dhatvadi varga, Sandhan kalpana $3 \quad(3.65 \%)$ drugs were mentioned. Least importance was given to food products including Mamsa varga, Krutanna varga, Dugdha varga, Dadhi varga, Takra varga, Navaneet varga, Taila varga and madhu varga each respectively $1(1.22 \%)$ for treating hemorrhoids. Dhanya, Vari, Ghruta, Mutra, Ikshu varga have no anti-hemorrhoid drugs. 


\begin{tabular}{|c|c|c|c|}
\hline S. No. & Name of the varga & Total drugs & Percentage (\%) \\
\hline 1 & Haritakyadi & 12 & 14.63 \\
\hline 2 & Karpuradi & 6 & 7.31 \\
\hline 3 & Guduchyadi & 27 & 32.92 \\
\hline 4 & Pushpa & 2 & 2.43 \\
\hline 5 & Vatadi & 8 & 9.75 \\
\hline 6 & Amradiphala & 2 & 2.43 \\
\hline 7 & Shaka & 8 & 9.75 \\
\hline 8 & Dhatwadi & 6 & 7.31 \\
\hline 9 & Sandhan & 3 & 3.65 \\
\hline 10 & Mamsa & 1 & 1.22 \\
\hline 11 & Krutanna & 1 & 1.22 \\
\hline 12 & Dugdha & 1 & 1.22 \\
\hline 13 & Dadhi & 1 & 1.22 \\
\hline 14 & Takra & 1 & 1.22 \\
\hline 15 & Navaneet & 1 & 1.22 \\
\hline 16 & Taila & 1 & 1.22 \\
\hline 17 & Madhu & 1 & 1.22 \\
\hline & Total & 82 & $100 \%$ \\
\hline
\end{tabular}

For treatment of hemorrhoids, the recommendation is 30 $35 \mathrm{~g}$ of daily fiber. Dietary sources include beans, fruits, vegetables and whole grains. Dried figs, prunes, blackberries, boysenberries, raspberries, pears, chickpeas, kidney and pinto beans, lentils, brown rice, and oat bran cereals have high fiber content. Numerous fiber supplements are available. Most fiber products are bulking agents that soften the stool by absorbing water. Psyllium is a natural source of pure fiber, sold in powder form from the husks of seeds from the psyllium plant. Patients who are unable to tolerate psyllium-based products because of excessive gas or bloating can try Fibercon or Benefiber. Patients should be advised to increase fiber supplementation gradually and in conjunction with adequate fluid intake (six to eight glasses of a no caffeinated beverage daily) and increase in daily activity so as to avoid constipation. To promote patients' compliance with fiber supplementation, it is important to explain the other health benefits of fiber, such as decreasing the incidence of colon cancer and diverticular disease, controlling blood cholesterol levels, improving control of diabetes, and aiding in weight control. Behavioral modification; such as avoidance of prolonged sitting on the toilet, reading while defecating and excessive straining etc can alleviate some of the symptoms. Sitz baths (warm water, ten minutes, twice a day and no additives in the water) are helpful to patients with anal itching, aching, or burning and those with thrombosed hemorrhoids. Numerous over-the-counter creams and products are available, but most are ineffective or provide little relief. Many patients gets benefit from zinc oxide cream or Calmoseptine, which is available over the counter, applied as needed once or twice a day inside and outside the anus. Short courses of hydrocortisone $1 \%$ pramoxine hydrochloride $1 \%$ (local anesthetic) cream or $25-\mathrm{mg}$ hydrocortisone suppositories once or twice a day can be helpful. Patients with bleeding and prolapsed internal hemorrhoids refractory to conservative treatment can undergo ablation. Several office-based procedures are available, including injection sclera therapy, infrared coagulation and rubber-band ligation. All procedures accomplish shrinkage and scarring of the internal hemorrhoids. Rubber-band ligation has been the most effective of these modalities. Patients should refrain from taking NSAIDS or anticoagulation for one week prior to and one week after rubber-band ligation to minimize the risk of bleeding. At the initial office visit, it is preferable to ligate one hemorrhoid; if the procedure is well tolerated, the patient can undergo multiple ligations at subsequent visits. The procedure should be relatively painless as long as the internal hemorrhoid is ligated above the dentate line. If the patient experiences sharp or severe pain when the bundle is grasped, then a different hemorrhoid should be tried; if pain persists, the procedure should be abandoned. It is usual practice to ligate the hemorrhoid that looks most inflamed or irritated at time of the visit. Some patients have a vasovagal reaction immediately after the procedure, so care must be taken to get the patient gradually off the procedure table. Patients are instructed to take Tylenol and use sitz baths as needed for the dull ache after ligation that usually lasts for 24 to 48 hours. Although ligation is a safe procedure, severe bleeding and sepsis have been reported to result in some patients. Patients should seek immediate care if any of the following symptoms develop: fever, chills, abdominal or pelvic pain, continuous rectal bleeding, purulent anal drainage, and urinary retention. The rubber band can fall off soon after the procedure or up to three weeks later. Patients can usually return to work or normal daily activities after the procedure. ${ }^{19}$ 
Table 1: Drugs of Haritakyadi varga on piles with respective references

\begin{tabular}{|c|c|c|c|}
\hline Drug Name & Family & Action of drug & Corresponding reference ${ }^{\#}$ \\
\hline $\begin{array}{c}\text { Haritaki } \\
\text { (Terminalia chebula Retz, Terminalia cetrina Roxb) }\end{array}$ & Combretaceae & Arshoghna & B.P.N.1/20 \\
\hline $\begin{array}{c}\text { Shunthi } \\
\text { (Zingiber officinale Roscoe) }\end{array}$ & Zingiberaceae & Arshoghna & B.P.N.1/46 \\
\hline $\begin{array}{c}\text { Pippali } \\
\text { (Piper longum Linn., Chavica roxburghii) }\end{array}$ & Piperaceae & Arshoghna & B.P.N.1/55 \\
\hline $\begin{array}{c}\text { Chavya } \\
\text { (Piper chaba Hunter, Piper officinarum Cas D.C.) }\end{array}$ & Piperaceae & $\begin{array}{c}\text { Visheshat } \\
\text { Gudajapaham }\end{array}$ & B.P.N.1/67 \\
\hline $\begin{array}{c}\text { Chitrak } \\
\text { (Plumbago zeylanica } \text { Linn.) }\end{array}$ & Plumbaginaceae & Arshoghna & B.P.N.1/71 \\
\hline $\begin{array}{c}\text { Hapush Dwaya } \\
\text { (Juniperus communis Linn.) }\end{array}$ & Cupressaceae & Arshoghna & B.P.N.1/109 \\
\hline $\begin{array}{c}\text { Indrayava } \\
\text { (Holarrhena antidysenterica } \text { Wall.) }\end{array}$ & Apocynaceae & Raktarsha & B.P.N.1/159 \\
\hline $\begin{array}{c}\text { Kataphala } \\
\text { (Myrica nagi Thunb.) }\end{array}$ & Myricaceae & Arshoghna & B.P.N.1/181 \\
\hline $\begin{array}{c}\text { Pashanbheda } \\
\text { (Saxifraga ligulata Wall) }\end{array}$ & Saxifragaceae & Arshoghna & B.P.N.1/185 \\
\hline $\begin{array}{c}\text { Lashuna } \\
\text { (Allium sativum Linn.) }\end{array}$ & Liliaceae & Durnamhara & B.P.N.1/223 \\
\hline $\begin{array}{c}\text { Bhallataka } \\
\text { (Semecarpus anacardium Linn.) }\end{array}$ & Anacardiaceae & Arshoghna & B.P.N.1/230,232 \\
\hline $\begin{array}{c}\text { Yavakshar } \\
\text { (Potasii carbonas) }\end{array}$ & - & Arshoghna & B.P.N.1/254 \\
\hline
\end{tabular}

Table 2: Drugs of Karpuradi varga on piles with respective references

\begin{tabular}{|c|c|c|c|}
\hline Drug Name & Family & Action of drug & Corresponding reference ${ }^{\#}$ \\
\hline $\begin{array}{c}\text { Guggulu } \\
\text { (Balsamodendron mukul Hook.ex Stocks) }\end{array}$ & Burseraceae & Arshoghna & B.P.N.2/40 \\
\hline $\begin{array}{c}\text { Sukshma Ela } \\
\text { (Elettaria cardamomum Maton) }\end{array}$ & Zingiberaceae & Arshoghna & B.P.N.2/63 \\
\hline $\begin{array}{c}\text { Twakpatra } \\
\text { (Cinnamomum cassia } \text { Blume) }\end{array}$ & Lauraceae & Arshoghna & B.P.N.2/65 \\
\hline $\begin{array}{c}\text { Tamalpatra } \\
\text { (Cinnamomum tamal Nees and Eberm) }\end{array}$ & Lauraceae & Arshoghna & B.P.N.2/68 \\
\hline $\begin{array}{c}\text { Shaileyam } \\
\text { (Parmelia perlata Ach.) }\end{array}$ & Parmeliaceae & Gudaraktahruta & B.P.N.2/91 \\
\hline $\begin{array}{c}\text { Karchura } \\
\text { (Curcuma zedoaria Rosc.) }\end{array}$ & Zingiberaceae & Arshoghna & B.P.N.2/96 \\
\hline
\end{tabular}

Table 3: Drugs of Guduchyadi varga on piles with respective references

\begin{tabular}{|c|c|c|c|}
\hline Drug Name & Family & Action of drug & Corresponding reference ${ }^{\#}$ \\
\hline $\begin{array}{c}\text { Guduchi } \\
\text { (Tinospora cordifolia } \text { Willd.) }\end{array}$ & Menispermiaceae & Arshoghna & B.P.N.3/10 \\
\hline $\begin{array}{c}\text { Gambhari } \\
\text { (Gmelina arborea } \text { Linn.) }\end{array}$ & Verbenaceae & Arshoghna & B.P.N.3/16 \\
\hline $\begin{array}{c}\text { Shonyak } \\
\text { (Oroxylum indicum Vent.) }\end{array}$ & Bignoniaceae & Arshoghna & B.P.N.3/28 \\
\hline $\begin{array}{c}\text { Gokshur } \\
\text { (Tribulus terrestris Linn.) }\end{array}$ & Zygophyllaceae & Arshoghna & B.P.N.3/46 \\
\hline $\begin{array}{c}\text { Mudgaparni } \\
\text { (Phaseolus trilobus Ait.) }\end{array}$ & Leguminosae & Arshoghna & B.P.N.3/54 \\
\hline $\begin{array}{c}\text { Erand Phala } \\
\text { (Ricinus communis Linn.) }\end{array}$ & Euphorbiaceae & Arshoghna & B.P.N.3/66 \\
\hline $\begin{array}{c}\text { Arkadwaya } \\
\text { (Calatropis gigantea Linn.) R.Br.ex Ait, } \\
\text { (Calotropis procera Ait) R.Br. }\end{array}$ & Asclepiadaceae & Arshoghna & B.P.N.3/69-70 \\
\hline $\begin{array}{c}\text { Sehunda } \\
\text { (Euphorbia neriifolia Linn.) }\end{array}$ & Euphorbiaceae & Arshoghna & B.P.N.3/75 \\
\hline $\begin{array}{c}\text { Kalihari } \\
\text { (Gloriosa superba Linn.) }\end{array}$ & Liliaceae & Arshoghna & B.P.N.3/80 \\
\hline $\begin{array}{c}\text { Nimba Phala } \\
\text { (Azadirachta indica A.Juss) }\end{array}$ & Meliaceae & Arshoghna & B.P.N.3/96 \\
\hline $\begin{array}{c}\text { Mahanimba } \\
\text { (Melia azedarach) }\end{array}$ & Meliaceae & Arshoghna & B.P.N.3/99 \\
\hline $\begin{array}{c}\text { Kutaj } \\
\text { (Holarrhena antidysenterica } \text { Wall.) }\end{array}$ & Apocynaceae & Arshoghna & B.P.N.3/118 \\
\hline $\begin{array}{l}\text { Karanja Patra and Phala } \\
\text { (Pongamia glabra } \text { Vent.) }\end{array}$ & Leguminosae & Arshoghna & B.P.N.3/120-22 \\
\hline
\end{tabular}




\begin{tabular}{|c|c|c|c|}
\hline $\begin{array}{c}\text { Karanji } \\
\text { (Holoptelia integrifolia } \text { Planch) }\end{array}$ & Ulmaceae & Arshoghna & B.P.N.3/124 \\
\hline $\begin{array}{c}\text { Vetas } \\
\text { (Salix caprea } \text { Linn.) }\end{array}$ & Salicaceae & Arshoghna & B.P.N.3/136 \\
\hline $\begin{array}{c}\text { Shatavari Ankur } \\
\text { (Asparagus racemosus Willd.) }\end{array}$ & Liliaceae & Arshoghna & B.P.N.3/188 \\
\hline $\begin{array}{c}\text { Mahashatavari Ankur } \\
\text { (Asparagus sarmentosus Linn.) }\end{array}$ & Liliaceae & Arshoghna & B.P.N.3/188 \\
\hline $\begin{array}{c}\text { Dantidwaya } \\
\text { (Baliospermum montanum Muell-Arg.) } \\
\text { (Croton tiglium Linn.) }\end{array}$ & Euphorbiaceae & Gudankurnash & B.P.N.3/200 \\
\hline $\begin{array}{c}\text { Vruddhadaruk } \\
\text { (Argyreia speciosa, } \text { Sweet) }\end{array}$ & Convolvulaceae & Arshoghna & B.P.N.3/212 \\
\hline $\begin{array}{c}\text { Mundi and Mahamundi } \\
\text { (Sphaeranthus indicus Linn.) } \\
\text { (Sphaeranthus amaranthoides) }\end{array}$ & Compositae & Gudartinash & B.P.N.3/217-18 \\
\hline $\begin{array}{c}\text { Apamarga } \\
\text { (Achyranthes aspera, Linn.) }\end{array}$ & Amaranthaceae & Arshoghna & B.P.N.3/220 \\
\hline $\begin{array}{c}\text { Asthishrunkhala } \\
\text { (Cissus quadrangularis, Wall.) }\end{array}$ & Vitaceae & Durnamghna & B.P.N.3/227 \\
\hline $\begin{array}{c}\text { Trayamana } \\
\text { (Delphinium zalil Aitch.and Hemsl) }\end{array}$ & Ranunculaceae & Arshoghna & B.P.N.3/243 \\
\hline $\begin{array}{c}\text { Kakmachi } \\
\text { (Solanum nigrum Linn.) } \\
\end{array}$ & Solanaceae & Arshoghna & B.P.N.3/247 \\
\hline $\begin{array}{c}\text { Kaknasa } \\
\text { (Asclepias curassavica Linn.) }\end{array}$ & Asclepiadaceae & Arshoghna & B.P.N.3/249 \\
\hline $\begin{array}{c}\text { Hingupatri } \\
\text { (Gardenia gummifera } \text { Linn.) }\end{array}$ & Rubiaceae & Arshoghna & B.P.N.3/264 \\
\hline $\begin{array}{c}\text { Devadali } \\
\text { (Luffa echinata Roxb.) }\end{array}$ & Cucurbitaceae & Arshoghna & B.P.N.3/292-93 \\
\hline
\end{tabular}

Table 4: Drugs of Pushpa varga on piles with respective references

\begin{tabular}{|c|c|c|c|}
\hline Drug Name & Family & Action of drug & Corresponding reference $^{\#}$ \\
\hline $\begin{array}{c}\text { Savartika/Karnika/Navkamalpatra } \\
\text { (Nelumbium speciosum Willd.) }\end{array}$ & Nymphaeaceae & Gudavyadhihara & B.P.N.4/9 \\
\hline $\begin{array}{c}\text { Kinjala/Kamal keshar } \\
\text { (Nelumbium speciosum Willd) }\end{array}$ & Nymphaeaceae & Raktarsh hara & B.P.N.4/11 \\
\hline
\end{tabular}

Table 5: Drugs of Vatadi varga on piles with respective references

\begin{tabular}{|c|c|c|c|}
\hline Drug Name & Family & Action of drug & Corresponding reference ${ }^{\#}$ \\
\hline $\begin{array}{l}\text { Kakoudumbarika } \\
\text { (Ficus hispida Linn.) }\end{array}$ & Moraceae & Arshoghna & B.P.N.5/10 \\
\hline $\begin{array}{c}\text { Palash } \\
\text { (Butea frondosa Koen.ex Roxb.) }\end{array}$ & Leguminosae & $\begin{array}{l}\text { Arshoghna, } \\
\text { Gudajrogjit, }\end{array}$ & B.P.N.5/50,53 \\
\hline $\begin{array}{c}\text { Dhava } \\
\text { (Anogeissus latifolia Wall.) } \\
\end{array}$ & Combretaceae & Arshoghna & B.P.N.5/60 \\
\hline $\begin{array}{c}\text { Karir } \\
\text { (Capparis aphylla } \text { Roth.) }\end{array}$ & Capparidaceae & Durnamhara & B.P.N.5/63 \\
\hline $\begin{array}{c}\text { Shakhot } \\
\text { (Streblus asper Lour.) }\end{array}$ & Moraceae & Arshoghna & B.P.N.5/64 \\
\hline $\begin{array}{c}\text { Katabhi } \\
\text { (Careya arborea } \text { Roxb.) } \\
\end{array}$ & Lecythidaceae & Arshoghna & B.P.N.5/67 \\
\hline $\begin{array}{c}\text { Jalashirishika } \\
\text { (Trichodesma zeylanicumR.Br.) }\end{array}$ & Boraginaceae & Arshoghna & B.P.N.5/71 \\
\hline $\begin{array}{c}\text { Shami } \\
\text { (Prosopis spicigera Linn.) }\end{array}$ & Leguminosae & Arshoghna & B.P.N.5/73 \\
\hline
\end{tabular}

Table 6: Drugs of Amradiphala varga on piles with respective references

\begin{tabular}{|c|c|c|c|}
\hline Drug Name & Family & Action of drug & Corresponding reference $^{\#}$ \\
\hline $\begin{array}{c}\text { Lavali } \\
\text { (Cicca acida } \text { Linn, } \text { Merrill }\end{array}$ & Euphorbiaceae & Arshoghna & B.P.N.6/80 \\
\hline $\begin{array}{c}\text { Vrukshamla } \\
\text { (Garcinia } \text { indica } \text { Chois. })\end{array}$ & Guttiferae & Arshoghna & B.P.N.6/149 \\
\hline
\end{tabular}

Table 7: Drugs of Dhatwadi varga on piles with respective references

\begin{tabular}{|c|c|c|c|}
\hline Drug Name & English Name & Action of drug & Corresponding reference $^{\#}$ \\
\hline Tamra bhasma & Copper $(\mathrm{Cu})$ & Arshoghna & B.P.N.7/27 \\
\hline Louha & Iron $(\mathrm{Fe})$ & Arshoghna & B.P.N.7/42 \\
\hline Kanthouha & Magnetic iron ore or Magnetite & Arshoghna & B.P.N.7/49 \\
\hline Swarnamakshika & Copper pyrite & Arshoghna & B.P.N.7/60 \\
\hline Tarmakshika & Pyrite & Arshoghna & B.P.N.7/81 \\
\hline Shilajit & Mineral Pitch & Vatarsha & \\
\hline
\end{tabular}


Satej Banne et al / Int. J. Res. Ayurveda Pharm. 5(4), Jul - Aug 2014

Table 8: Drugs of Shaka varga on piles with respective references

\begin{tabular}{|c|c|c|c|}
\hline Drug Name & Family & Action of drug & Corresponding reference $^{\#}$ \\
\hline $\begin{array}{c}\text { Vastuk } \\
\text { (Chenopodium album Linn.) }\end{array}$ & Chenopodiaceae & Arshoghna & B.P.N.9/7 \\
\hline $\begin{array}{c}\text { Loni } \\
\text { (Portulaca quadrifida Linn.) }\end{array}$ & Portulacaceae & Arshoghni & B.P.N.9/21 \\
\hline $\begin{array}{c}\text { Changeri } \\
\text { (Oxalis corniculata Linn.) }\end{array}$ & Oxalidaceae & Arshoghna & B.P.N.9/24 \\
\hline $\begin{array}{c}\text { Shwet Vruntak } \\
\text { (Solanum melongena Linn.) }\end{array}$ & Solanaceae & $\begin{array}{c}\text { Arshasu } \\
\text { Visheshen }\end{array}$ & B.P.N.9/82 \\
\hline $\begin{array}{c}\text { Dodika } \\
\text { (Leptadenia reticulate W.and A.) }\end{array}$ & Asclepiadaceae & Arshoghna & B.P.N.9/88 \\
\hline $\begin{array}{c}\text { Surankanda } \\
\text { (Amorphophalus campanulatus Blume.) }\end{array}$ & Araceae & $\begin{array}{c}\text { Arshasu } \\
\text { Visheshen }\end{array}$ & B.P.N.9/90,91 \\
\hline $\begin{array}{c}\text { Grunjan } \\
\text { (Daucus carota var. sativa DC.) }\end{array}$ & Umbelliferae & Arshoghna & B.P.N.9/88 \\
\hline $\begin{array}{c}\text { Hastikarna } \\
\text { (Leea macrophylla Horn.) }\end{array}$ & Vitaceae & Arshoghna & B.P.N.9/109 \\
\hline
\end{tabular}

Table 9: Drugs of Mamsa varga on piles with respective references

\begin{tabular}{|c|c|c|c|}
\hline Drug Name & Name of Animal & Action of drug & Corresponding reference $^{\#}$ \\
\hline Parnamruga & Monkey & Arshoghna & B.P.N.10/19 \\
\hline
\end{tabular}

Table 10: Drugs of Krutanna (food preparations) varga on piles with respective references

\begin{tabular}{|c|c|c|}
\hline Drug Name & Action of drug & Corresponding reference $^{\#}$ \\
\hline Bedhai & Gudakila nash & B.P.N.11/43 \\
\hline
\end{tabular}

Table 11: Drugs of Dugdha (milk and milk preparations) varga on piles with respective references

\begin{tabular}{|c|c|c|}
\hline Drug Name & Action of drug & Corresponding reference $^{\#}$ \\
\hline Dugdha & Gudankur nash & B.P.N.13/05 \\
\hline
\end{tabular}

Table 12: Drugs of Dadhi (curd preparations) varga on piles with respective references

\begin{tabular}{|c|c|c|}
\hline Drug Name & Action of drug & Corresponding reference $^{\#}$ \\
\hline Aja Dadhi (Goat's curd) & Arshohara & B.P.N.14/12 \\
\hline
\end{tabular}

Table 13: Drugs of Takra (butter milk preparations) varga on piles with respective references

\begin{tabular}{|c|c|c|}
\hline Drug Name & Action of drug & Corresponding reference $^{\#}$ \\
\hline Ghol takra along with Hingu, Jirak, Saindhava lavan & Arshohara & B.P.N.15/12,15 \\
\hline
\end{tabular}

Table 14: Drugs of Navaneet (butter preparations) varga on piles with respective references

\begin{tabular}{|c|c|c|}
\hline Drug Name & Action of drug & Corresponding reference $^{\#}$ \\
\hline Navaneet & Arshohara & B.P.N.16/2 \\
\hline
\end{tabular}

Table 15: Drugs of Taila (oils preparations) varga on piles with respective references

\begin{tabular}{|c|c|c|}
\hline Drug Name & Action of drug & Corresponding reference $^{\#}$ \\
\hline Sarshapa taila & Arshohara & B.P.N.19/13 \\
\hline
\end{tabular}

Table 16: Drugs of Sandhan (alcohol preparations) varga on piles with respective references

\begin{tabular}{|c|c|c|}
\hline Drug Name & Action of drug & Corresponding reference $^{\#}$ \\
\hline Souvira & Arshohara & B.P.N.20/9 \\
\hline Sura & Arshohara & B.P.N.20/23 \\
\hline Sidhu & Arshohara & B.P.N.20/27 \\
\hline
\end{tabular}

Table 17: Drugs of Madhu (Honey preparations) varga on piles with respective references

\begin{tabular}{|c|c|c|}
\hline Drug Name & Action of drug & Corresponding reference $^{\#}$ \\
\hline Makshika & Arshohara & B.P.N.21/4,8 \\
\hline
\end{tabular}

\# - B.P.N. Bhavaprakash Nighantu, first number is corresponding number of varga, and second number is respective verse 


\section{CONCLUSION}

The present review on anti-hemorrhoid drugs of Bhavaprakash Nighantu is original of its kind- Total 82 drugs are mentioned by Bhavaprakash Nighantu comprising herbal, mineral and animal origin drugs. All the drugs have been mentioned as Arshoghna but the mode of action has not been detailed. A detailed clinical study is required to understand the mode of action of these drugs.

\section{REFERENCES}

1. http://www.rightdiagnosis.com/h/hemorrhoids/statscountry.htm\#extrapwarning; 2014.

2. http://www.thehealthsite.com/topics/lifestyle-diseases-diseasesconditions/

3. http://www.slideshare.net/drbrajeev/life-style-diseases- 15857440

4. Digestive diseases in the United States: Epidemiology and Impact NIH Publication No. 94-1447, http://www.rightdiagnosis.com/h/hemorrhoids/basics.htm; 1994.

5. http://www.rightdiagnosis.com/h/hemorrhoids/intro.htm

6. PV Sharma, Susruta-Samhita with English translation of text and Dalhana's commentary along with critical notes, Vol. II, Chaukhambha Vishvabharati Oriental publishers and distributors, first edition, Arshonidana, Shloka no.3; 2000. p. 19.

7. PV Sharma, Caraka Samhita, Agnivesa's treatise refined and annotated by Caraka and redacted by Drdhabala, Vol. I, Chaukhambha Orientalia, Edition sixth, Dashapranayataniya Adhyaya, Shloka no 3-4; 2000. p. 232.

8. Dr PS Byadgi, Ayurvediya vikruti vijnana and roga vinana, Vol. I, Chaukhambha publications, New Delhi, Edition first, Chapter 12, Asta Mahagada; 2007. p. 228-29.

9. PV Sharma, Susruta-Samhita with English translation of text and Dalhana's commentary along with critical notes, Vol. II, Chaukhambha Vishvabharati Oriental publishers and distributors, first edition, Garbhavyakaran Shareer, Shloka no.26; 2000. p. 155.

10. PV Sharma, Caraka Samhita, Agnivesa's treatise refined and annotated by Caraka and redacted by Drdhabala, Vol. I, Chaukhambha Orientalia, Edition sixth, Strotoviman Adhyaya, Shloka no 8, 21; 2000. p. 329-32.

11. PV Sharma, Susruta-Samhita with English translation of text and Dalhana's commentary along with critical notes, Vol. II, Chaukhambha Vishvabharati Oriental publishers and distributors, first edition, Garbhavyakaran Shareer, Shloka no.5, 8; 2000. p. 15152.

12. PV Sharma, Caraka Samhita, Agnivesa's treatise refined and annotated by Caraka and redacted by Drdhabala, Vol. I, Chaukhambha Orientalia, Edition sixth, Vividhashitapitiya Adhyaya, Shloka no 13-14; 2000. p. 229.

13. PV Sharma, Susruta-Samhita with English translation of text and Dalhana's commentary along with critical notes, Vol. II, Chaukhambha Vishvabharati Oriental publishers and distributors, first edition, Arshonidan, Shloka no.8; 2000. p. 20.

14. PV Sharma, Susruta-Samhita with English translation of text and Dalhana's commentary along with critical notes, Vol. II, Chaukhambha Vishvabharati Oriental publishers and distributors, first edition, Avaraniya Adhyaya, Chapter 33, Shloka no.10; 2000. p. 318.

15. PV Sharma, Susruta-Samhita with English translation of text and Dalhana's commentary along with critical notes, Vol. II, Chaukhambha Vishvabharati Oriental publishers and distributors, first edition, Arsha chikitsa, Chapter 6, Shloka no.13, 19, 22; 2000. p. 334-39.

16. PV Sharma, Susruta-Samhita with English translation of text and Dalhana's commentary along with critical notes, Vol. II, Chaukhambha Vishvabharati Oriental publishers and distributors, first edition, Arsha chikitsa, Chapter 6, Shloka no.13, 19, 22; 2000. p. $334-39$.

17. Kaviraj Atrideva Gupta, Shrimad Vagbhata Virachitam Ashtang Hridayam, Vidyodini Bhasha Teeka-Vaktavya-Parishishtasahitam, Chaukhambha Sanskrit Sansthan, Varanasi, Reprint edition, Shodhanadigana sangraha Adhyaya, Chapter no.15, Shloka no. 32, 34; 2005. p. 106.

18. PV Sharma, Susruta-Samhita with English translation of text and Dalhana's commentary along with critical notes, Vol. II, Chaukhambha Vishvabharati Oriental publishers and distributors, first edition, Dravyasangrahaniya Adhyaya, Chapter no. 38, Shloka no. $21 ; 2000$. p. 358 .

19. Herman Villalba, MD and Maher A Abbas. Hemorrhoids: Modern Remedies for an Ancient Disease. Perm J 2007; 11(2): 74-76.

Cite this article as:

Satej Banne, Shraddha Nayak, Yogesh Girigaon, Nalinikanta Parida,

Mahantkumar Naik. Anti-hemorrhoidal drugs of Bhavaprakash nighantu: A literary survey. Int. J. Res. Ayurveda Pharm. 2014;5(4):551557 http://dx.doi.org/10.7897/2277-4343.054111 